\title{
Nüfuz Pazarlamasında (Influencer Marketing) Mesaj Stratejileri
}

\author{
Aysel Aktaş (Öğr. Gör.) \\ Beykent Üniversitesi Meslek Yüksekokulu \\ ayselaktas@beykent.edu.tr \\ Orcid: 0000-0002-8788-144X \\ Gül Şener (Dr. Öğr. Üyesi) \\ Bahçeşehir Üniversitesi İletişim Fakültesi \\ gul.sener@comm.bau.edu.tr \\ Orcid: 0000-0002-8063-7233
}

Başvuru Tarihi: 01.11.2018

Yayına Kabul Tarihi: 27.12.2018

Yayınlanma Tarihi: 21.01.2019

\section{Öz}

Sosyal medya reklamverenlerin hedef kitlelerine ulaşma ve iletişim kurma biçimlerini de dönüştürmüştür. Tüketiciler tarafından güvenilir ve samimi bilgi kaynakları olarak görülen ve sosyal medya ünlüleri olarak da nitelenen nüfuzlular (influencer), elektronik ağızdan ağıza (eWOM) iletişim uygulamalarında baş rolü üstlenmişlerdir. Dolayısıyla, markalar için Nüfuz Pazarlaması (Influencer Marketing) pazarlama bütçelerinin ayrılmaz bir parçası haline gelmiştir. Nüfuzluların ürettikleri içerikler, takipçileriyle kurdukları iletişim ve hayata geçirdikleri marka birliktelikleri çerçevesinde uyguladıkları yöntemlerin başında ise ürün yerleştirme gelmektedir.

Bu çalışmanın amacı; genel anlamda sosyal medyada, özelde Instagram çerçevesinde farklı hesap kategorilerinde (Moda, Gezi-Seyahat, Makyaj-Güzellik, Sağlık-Yaşam) içerik üreten nüfuzluların yaptıkları ürün yerleştirmeleri hangi mesaj stratejisi ile ele aldıklarını incelemektir. Araștırma kapsamında, 8 makro nüfuzlunun 799 Instagram paylaşımı içerik analizi yöntemiyle incelenmiş ve bulgular paylaşılmıştır. Çalışmanın sonuçları, makro nüfuzluların en çok transformasyonel (dönüşümsel) mesaj stratejilerini kullandıklarını ve tüketicileri duygusal çekiciliklerle etkilemeye çalıştıklarını ortaya koymaktadır.

Anahtar Kelimeler: Nüfuz Pazarlaması (Influencer Marketing), Ürün Yerleştirme, Instablogger, İçerik Analizi, Mesaj Stratejileri. 


\title{
Message Strategies Used in Influencer Marketing
}

\author{
Aysel Aktaş (Lect) \\ Beykent University Vocational School \\ ayselaktas@beykent.edu.tr \\ Orcid: 0000-0002-8788-144X \\ Gül Şener (Asst. Prof. Dr.) \\ Bahçeşehir University Faculty of Communication \\ gul.sener@comm.bau.edu.tr \\ Orcid: 0000-0002-8063-7233
}

Date Received: 01.11.2018

Date Accepted: 27.12.2018

Date Published: 21.01.2019

\section{Abstract}

Social media had transformed the way advertisers reach their target consumers and connect with them. Influencers who are perceived as sincere and credible sources by the consumers are called the new pioneers of electronic word-of-mouth (eWOM). In parallel, Influencer Marketing became an indispensable part of the marketing budgets. Within this perspective, product placement is one of the primary means that influencers prefer while partnering with brands, creating content and delivering it to their followers.

The objective of this study is to examine message strategies that influencers use when implementing product placements. Within the confines of this research 799 Instagram posts by 8 macro influencers were subject to content analysis. The results show that macro influencers use transformational message strategies the most when doing product placements.

Keywords: Influencer Marketing, Product Placement, Instablogger, Content Analysis, Message Strategies. 


\section{Giriş}

İletişim ve bilgi teknolojilerindeki gelişmelerin yanı sıra sosyal medyanın yükselişiyle birlikte markaların mesajlarını tüketiciyle buluşturduğu mecralar da çeşitlilik kazanmıştır. Bu çeşitlilik içerisinde günümüz markaları giderek artan oranda dijital mecralara yönelmektedir. Reklamcılar Derneği Raporu (2018); Türkiye'de dijital mecralara yapılan medya ve reklam yatırımındaki 2016-2017 arası artış oranının toplam medya yatırım ortalamasının 3 katı olduğunu ortaya koymakta ve medya yatırımlarındaki büyümenin lokomotifinin dijital mecralar olduğunu göstermektedir. Dijitalleşme markaların hedef kitlelerine ulaşma yollarını değiştirmekle kalmamış aynı zamanda mesaj verme biçimlerini de etkilemiştir. Sosyal medya platformu şemsiye kavramı ile ifade edilen 280 karakter sınırlamalı mikroblog Twitter, fotoğraf ve video temelli içerik paylaşım siteleri Instagram ve Youtube (Osatuyi, 2013, 2622) markaların hedef kitlelerine verdikleri mesajların yapısını, içeriğini ve kullanılan stratejileri de dönüşüme uğratmıştır.

Pazarlama ve reklamcıların içerik stratejilerini etkileyen bir diğer gelişme de gün geçtikçe kullanımı artan reklam engelleyici (AdBlocker) yazılımlardır. Paige Fair'in yakın dönem yaptığı bir araştırma reklam engelleyici kullanımının 2016'da dünya çapında \%30 artığını ortaya koymaktadır ve reklamların tüketilmek istenen içeriği kesintiye uğratmasını bu yükselişin en önemli sebeplerinden biri olarak göstermektedir (O'Reilly, 2017). Türkiye'deki internet kullanıcılarının \%40'ı reklamları engelleyici uygulama kullanmaktadır (We Are Social, 2018). iAB Türkiye (2016) Reklam Engelleme Raporu'nda pazarlamacıları uyararak; reklamı öne çıkartmak gayesiyle tüketicinin ulaşmak istediği bilgi, servis ve içeriğe erişmesini engelleyen "saldırgan" reklamlardan vazgeçilmesi gerektiğini belirtmektedir.

Tüketicilerin artan orandaki reklamdan kaçınma davranışı Nüfuz Pazarlaması'nın da (Influencer Marketing) ortaya çıkışını ve kullanımını hızlandıran etmenlerden biri olmuştur. Geleneksel reklamlara güvenmeyen genç tüketicilere ulaşma ihtiyacı marka yetkililerinin Nüfuz Pazarlaması'nı temel tercih sebepleri arasındadır (Linqua, 2017, 2). Nielsen (2015) tarafından gerçekleştirilen bir araştırma Z ve Y jenerasyonu tüketicilerin tanıdıklarının tavsiyelerine ya da çevrimiçi tüketici paylaşımlarına geleneksel reklamlardan daha fazla güvendiğini bulgulamıştır. $\mathrm{Bu}$ çerçeveden değerlendirildiğinde; nüfuzluların (influencer) kullandıkları ya da beğendikleri ürün/servisleri takipçileriyle paylaşan sade vatandaşlarken popülerleşerek markaların içerik üreticileri haline gelmesi şaşırtıcı değildir. Günümüzde marka iletişimine dair daha derinlikli bir bakış kazanmanın yolu nüfuzluların kullandıkları mesaj stratejilerini anlamaktan geçmektedir.

Brown ve Hayes $(2008,45)$ nüfuzlu (influencer) kavramını "tüketicinin satın alma kararını belirgin biçimde şekillendiren ve bunun da sorumluluğunda olan bir üçüncü taraf" olarak tanımlamaktadır. Nüfuz Pazarlaması; etki sahibi kişininin yani nüfuzlunun - otoritesi, konumu, ilişkileri ve bilgisiyle tüketicilerin satın alma kararlarını etkilediği düşüncesinden ortaya çıkmaktadır. Bir elektronik ağızdan ağıza pazarlama (eWOM) biçimi olarak değerlendirilen Nüfuz Pazarlaması, bir markanın ürün ve hizmetlerini o markayı etkileme kapasitesine sahip kişiler aracılığıyla (nüfuzlu/influencer) tanıtma veya satma eylemlerinin tümünü kapsayan pazarlama etkinliği olarak tanımlanmaktadır (Huffpost, 2016). Instabloggerlar ve Youtuberlar ise hiç kuşkusuz bu yükselişteki pazarlama etkinliğinin ana oyuncuları konumundadır. Linqua'ya $(2018,8)$ göre Instagram, reklamcıların 
Nüfuz Pazarlaması uygulamaları bağlamında en çok önem atfettiği sosyal medya platformu konumundadır. Sosyal medya nüfuzlularının marka iletişimi bağlamında kullandıkları yöntemlerinin başında ise ürün yerleştirme gelmektedir (Kurutz, 2011). Ürün yerleştirmenin geleneksel mecralarda uygulanmasına dair geniş bir literatürden bahsetmek mümkündür. Ancak alan çalışmaları sosyal medya bağlamında oldukça kısıtlı kalmaktadır.

$\mathrm{Bu}$ çalışmanın amacı Instagram'da farklı hesap kategorilerinde (Moda, GeziSeyahat, Makyaj-Güzellik, Sağlık-Yaşam) içerik üreten nüfuzluların, yani Instabloggerların, yaptıkları ürün yerleştirmeleri hangi mesaj stratejisi ile ele aldıklarını incelemektir. Dolayısıyla, halihazırdaki araştırma geçmişten günümüze oluşturulan alan çalışmalarına ve sosyal medyada ürün yerleştirme literatüründe bulunan boşluğa katkı sunmayı amaçlamaktadır. Bu bağlamda, 8 Instabloggerın hesapları 1 Ocak 2018-28 Şubat 2018 tarihleri arasında incelenmiştir. Farklı kategorilerde (Moda, Gezi-Seyahat, Makyaj-Güzellik, Sağlık-Yaşam) paylaşımda bulunan Instabloggerların ürün yerleștirme uygulamalarında kullandıkları mesaj stratejileri ve bu mesaj stratejilerinin farklı etkileşim öğeleriyle ilişkisi içerik analizi yöntemiyle ortaya konmuştur.

\section{Teorik Çerçeve}

\subsection{Reklamda Mesaj Stratejisi: Tanım ve Tipolojiler}

Yüksel'e (2003, 12) göre mesaj "kaynaktan alıcıya gönderilen bir uyarı, bir düşünce, duygu, kanı ya da bilgilerin kaynak tarafından kodlanmış hali"dir. Reklam bağlamında düşünüldüğünde marka tarafından tüketicilere iletilen mesaj belirli bir iletişim stratejisi çerçevesinde şekillenmektedir. Taylor $(1999,7)$ mesaj stratejisini "bir şirket ya da kurumun ürünleri, hizmetleri ya da kurumsal markası için yaptığı pazarlama iletişimi faaliyetlerine rehberlik eden yaklaşım" olarak tanımlamaktadır. Diğer bir deyişle; mesaj stratejisi, markalı ürün ya da hizmetin tüketiciye faydasıyla ilgili reklamda ne söylenmesi gerektiğine dair bir yol haritası olarak düşünülebilir.

Puto ve Wells (1984) mesaj stratejilerini bilgisel ve transformasyonel (dönüşümsel) olmak üzere ikiye ayırmaktadır. Bilgisel reklamlar tüketiciyi markalı ürün ya da hizmetle ilgili rasyonel argümanlar üzerinden ikna etmeye çalışır. Bir reklamın bilgisel olarak değerlendirilmesi için belirli özelliklere sahip olması gerekmektedir: "(1) Markaya dair olgusal bilgi sunmass, (2) bu bilginin hedeflenen tüketiciye yönelik faydayı yansıtması, (3) tüketicinin sunulan bilgiyi ispatlanabilir olarak değerlendirmesi" (Puto ve Wells, 1984, 638). Bu tür reklamların "birincil amacı marka bilinirliğini ve marka özelliklerine dair inançları etkilemektir" (Aaker ve Stayman, 1992, 240-241). Diğer yandan transformasyonel (dönüşümsel) reklamlar “...markalı ürünü kullanma deneyimini sadece o markaya ait olduğu iddia edilen benzersiz duygusal niteliklerle ilişkilendiren” mesajlar içermektedir ve “... normal şartlarda tüketicinin sözkonusu reklama maruz kalmadan bu deneyimi tanımlandığı haliyle yaşamayacağı” (Puto ve Wells, 1984, 638) öngörülmektedir. Transformasyonel (dönüşümsel) reklamların ana hedefi "maruz kalma anında tüketicide duygusal bir tepki yaratmaktır" (Aaker ve Stayman, 1992, 240). Aaker ve Norris $(1982,61)$ bu iki temel mesaj stratejisi yaklaşımının alan araştırmacıları tarafından "bilgisel/rasyonel/biliş temelli" ve "imaj odaklı/duygusal/his temelli" reklamlar olarak tanımlandığından bahsetmektedir. Laskey ve diğerleri $(1989,38)$ ise bu ana mesaj stratejilerinin alt açılımlarını da belirleyerek bir mesaj stratejisi tipolojisi oluşturmuşlardır. 
Tablo 1: Laskey ve diğerlerinin (1989) Ana Mesaj Stratejisi Tipolojisi

\begin{tabular}{|c|c|}
\hline BILGISEL MESAJLAR & $\begin{array}{l}\text { TRANSFORMASYONEL } \\
\text { (DÖNÜŞÜMSEL) MESAJLAR }\end{array}$ \\
\hline $\begin{array}{c}\text { Karşılaştırmalı } \\
\text { İki markalı ürün/hizmet arasında } \\
\text { doğrudan kıyaslama yapılır. }\end{array}$ & $\begin{array}{c}\text { Kullanıcı İmajı } \\
\text { Kullanıcıya ve hayat tarzına odaklanır. }\end{array}$ \\
\hline $\begin{array}{l}\text { Biricik Satış Vaadi } \\
\text { Nesnel olarak ispatlanabilir bir } \\
\text { ürün özelliği ya da fayda iddiasının } \\
\text { benzersizliğine dayanır. }\end{array}$ & $\begin{array}{c}\text { Marka İmajı } \\
\text { Belirli bir marka kişiliğini yansıtmayı } \\
\text { amaçlar. Genellikle kalite, } \\
\text { statü, prestij gibi özellikler } \\
\text { markaya atfedilir. }\end{array}$ \\
\hline $\begin{array}{c}\text { Öncü Üstünlük } \\
\text { Nesnel olarak ispatlanabilir bir ürün } \\
\text { özelliği ya da fayda iddiası barındırır. } \\
\text { Diğer markalarla rekabet ya da } \\
\text { biriciklik göndermesi barındırmaz. }\end{array}$ & $\begin{array}{l}\text { Kullanım Anı } \\
\text { Tüketicinin markalı ürün/hizmeti } \\
\text { kullanım deneyimine odaklanır. Ürün/ } \\
\text { hizmetin kullanılabileceği durumlar } \\
\text { ya da belirli deneyimlerle marka } \\
\text { arasında özdeşlik kurulmaya çalışılır. }\end{array}$ \\
\hline $\begin{array}{l}\text { Abartma } \\
\text { Nesnel olarak ispatlanabilir } \\
\text { olmayan bir ürün özelliği ya da } \\
\text { rasyonel fayda iddiası barındırır. } \\
\text { Genellikle olgusal gibi görünen } \\
\text { öznel değerlendirmeler biçiminde } \\
\text { yapılandırılmış bir argüman içerir. }\end{array}$ & $\begin{array}{c}\text { Jenerik } \\
\text { Belirli bir markaya değil } \\
\text { ürün kategorisine odaklanır. }\end{array}$ \\
\hline $\begin{array}{c}\text { Jenerik } \\
\text { Belirli bir markaya değil } \\
\text { ürün kategorisine odaklanır. }\end{array}$ & \\
\hline
\end{tabular}

Taylor (1999) mesaj stratejilerine yönelik çok katmanlı ve analitik bir yaklaşım getirmiştir. Ortaya koyduğu mesaj stratejisi çerçevesini reklam ve tüketici davranışı teorilerini entegre ederek oluşturmuştur. Bu bağlamda da iletişim stratejisi teorilerinden ve tüketici motivasyon teorilerinden yararlanmıştır. Belirlediği stratejileri bir çark sistemi çerçevesinde ifade etmektedir. Bu çarkın iki ana bölümü bulunmaktadır ve bu bölümler aynı zamanda iletişime (ve reklama) yönelik iki temel görüşün de ifadesidir: Bir mesaj "iletim" biçimi olarak iletişim ve bir "ritüel" olarak iletişim. Taylor'a göre iletişime yönelik bu iki temel kategori birbirini tamamlar niteliktedir.

"İletim" temelli yaklaşımda, iletişim "mesajların iletildiği ve belli bir zaman ve mekan bağlamında insanlar arasında dağıtıma sokulduğu bir süreç olarak tanımlanmaktadır" (Taylor 1999, 8). "Ritüel” temelli yaklaşımda ise iletişim; belirli bir bilginin bir vericiden bir alıcıya aktığı bir süreç olarak değil daha ziyade "insan davranışını şekillendiren ve kontrol eden düzenli ve anlamlı kültürel bir dünya inşa etmenin ve sürdürmenin aracı" (Taylor 1999, 8) olarak kabul edilmektedir. "İletim" görüşüne göre değerlendirildiğinde haber bir bilgi biçimidir, "ritüel" perspektifinden ise haber dramatik güç ve hareketleri resmeden bir drama biçimidir. Taylor bu iki ana perspektifin reklam bağlamında da değerlendirilebileceğini ve reklamdaki mesaj stratejilerinin temel temalarını oluşturabileceğini belirtmektedir. Bu çerçevede, "iletim" olarak reklam mesajını rasyonel, acil ihtiyaç ve rutin alt temalarıyla tanımlamakta, "ritüel" olarak reklam mesajını ise ego, sosyal ve duyusal alt temalarıyla çeşitlendirmektedir (Şekil 1). 


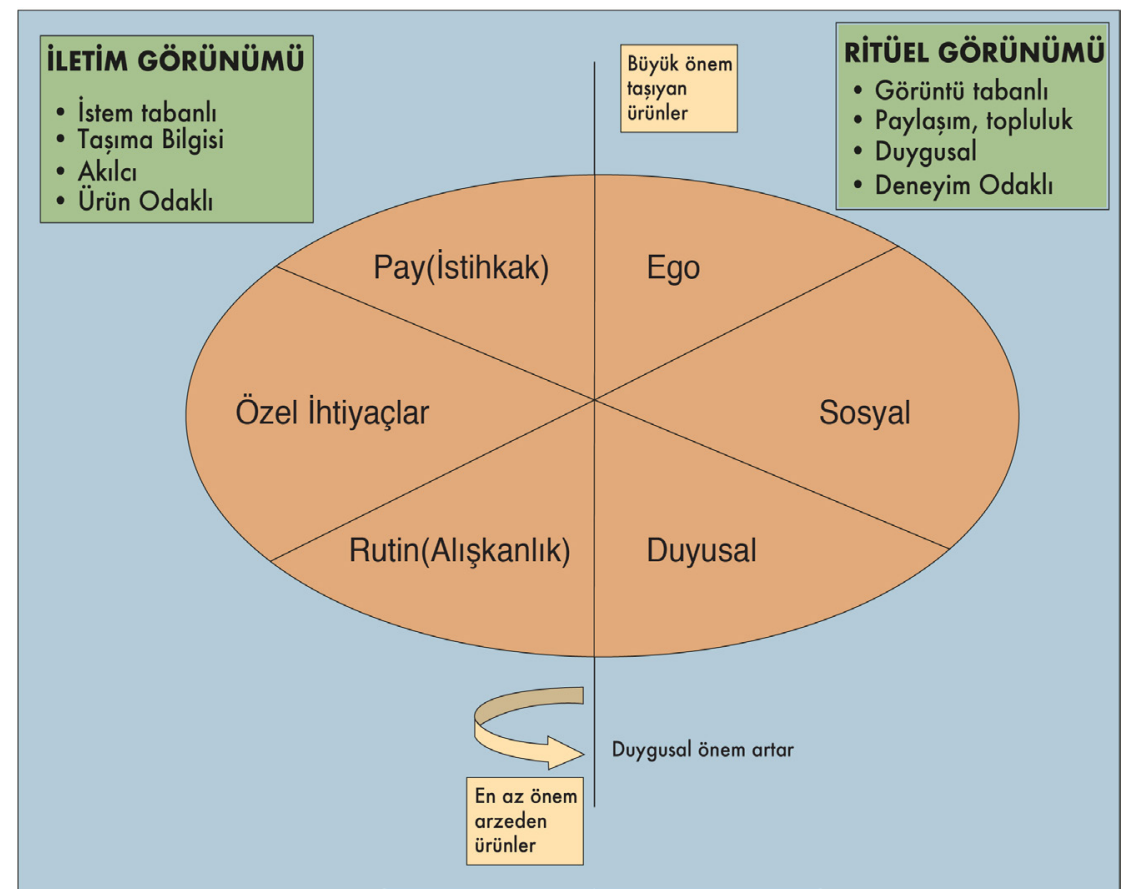

Şekil 1: Taylor'un 6 Parçalı Mesaj Strateji Çarkı

Taylor $(1999,12-13)$ mesaj strateji çarkında yer alan her bir alt temayı aşağıdaki biçimde tanımlamıştır:

- Ego: $\mathrm{Bu}$ tema çerçevesinde; tüketicilerin ürün kullanım ve satın alımları kendi bireysel imajlarını yansıtmak ya da iyileştirmek için birer araç olarak görülmektedir. Diğer bir deyişle, tüketicilerin kişisel imaj bağlantılı gereksinimleri ego ile ilişkili ürünlerle yerine getirilir. Kısaca, reklamverenler bu tür mesajlarla tüketicilere "Bu siz misiniz?" sorusunun yanıtını sunmaktadır. İletişimin rolü markalı ürünün ya da hizmetin tüketicinin kim olduğunu tanımladığına ve bu kimlikle nasıl da uyumlu olduğuna dikkat çekmektir.

- Sosyal: Bireye dönük ego temasının aksine sosyal temalı mesajlar çevreye odaklanır. Markalı ürünlerin kullanımı; dikkat çekmek, onaylanmak, saygı duyulmak, sevilmek ve beğenilmek gibi tüketicinin duygusal ihtiyaçlarını karşılamaya ya da belirli bir sosyal gruba ait olduklarını ifşa etmeye yarar. $\mathrm{Bu}$ mesaj teması referans kişileri satınalma kararına dahil etmeyi içermektedir.

- Duyusal: Tüketicilerin beș duyusuna seslenir. Markalı ürünler hayatın sunduğu ödüller olarak yansıtılır. Bu temayı esas alan marka mesajları, bir ürünü kullanmanın tüketiciye hayatın içindeki "keyif anlarını" yaşama imkanını nasıl sunduğunu anlatır.

- Rutin (Alışkanlık): Bu tema çerçevesinde üretilen mesajlar tüketici davranışının tekrar eden ve bir alışkanlığa işaret eden yönüne odaklanır. Temizlik ve kişisel bakım ürünleri bu tema çerçevesinde marka mesajı üreten tipik kategorilerdir. Bu tema bağlamında sıklıkla kullanılan çekicilikler arasında ürünün kolay ulaşılır olması, kullanım kolaylığı, kullanım sonrasındaki memnuniyet sayılabilir.

- Özel İhtiyaçlar: Tüketicilerin belirli bir ürüne yönelik acil ihtiyacını resmeden mesajları barındıran temadır. Tüketici ürünlere dair bilgi ihtiyacında olsa dahi zaman kısıtı sebebiyle halihazırda hangi ürün mevcutsa o kadarıyla kararını vermek durumundadır. Dolayısıyla, reklam mesajı ürünü tüketicinin zihinsel sepetine dahil etme amacı taşımaktadır. 
- Pay (İstihkak): Tüketicilerin; akılcı, bilinçli, hesapçı ve müzakereci bireyler olduğu varsayılır. Kısacası, bu tema çerçevesinde geliştirilen mesajlar düşünce ve mantığa dayanır. Bu tema, tüketicinin ürüne dair kalite, garanti süresi, fiyat vb. bilgileri aktif olarak aradığı anları tanımlamaktadır. İletişimin rolü bilgilendirmek ve ikna etmektir. Bu temaya dahil olan reklamlarda genelde rasyonel veriler ve bilgilendirici çekicilikler kullanılır.

\subsection{Nüfuzlu (Influencer) Kavramı ve Nüfuz Pazarlaması (Influencer Marketing)}

Nüfuzlu (influencer) kavramının kaynağını Katz ve Lazarsfeld'in (1955) “İki Aşamalı İletişim Modeli"nde bulmak mümkündür. Kişilerarası etki çalışmalarının öncüsü kabul edilen model, bir kaynak ve alıcı arasındaki bilgi akıșını aracılandıran kanaat önderlerinin varlığından bahsetmektedir. Bu kanaat önderlerinin işlevi medya mesajlarının anlamını ve içeriğini diğer medya kullanıcıları için yorumlamak ve sonrasında iletmektir (Lazarsfeld ve diğerleri, 1944). Tanımın da ortaya koyduğu üzere; kanaat önderleri, "toplulukların içerisindeki resmi bir güç ya da prestij pozisyonunu elinde bulunduran kișiler olmaktan öte kendi gibileri politik olaylar, toplumsal konular ve tüketici tercihleri konusunda uyarma ve yol gösterme görevi bulunan ara iletişim bağlantısı unsurlarıdır" (Nisbet ve Kotcher 2009, 329).

Bugünün dünyasında geçerli olan pazarlama yaklaşımları, değişen kitle iletişim araçlarının etkisi ile iki aşamalı iletişim modelinin klasik önermelerini yeni medya teknolojilerine uyarlayarak değișime uğratmıştır. Flynn ve diğerleri $(1996,138)$ kanaat önderlerini belirli bir ürün kategorisi çerçevesinde başkalarının satın alma davranışını etkileyen bireyler olarak tanımlamaktadır. Yapılan araştırmalar, kanaat önderlerinin daha yaratıcı, kitle medyasını yoğun kullanan, sosyal olarak aktif, ürüne yönelik ilginliği daha yüksek ve ürün kategorisi ile ilgili daha fazla deneyim ve uzmanlığı bulunan kişiler olduğunu ortaya koymaktadır (Flynn ve diğerleri, 1994; Yoo ve diğerleri, 2011). Lyons ve Henderson (2005, 325-326) çevrimiçi platformlardaki kanaat önderlerinin geleneksel muadilleriyle benzer özelliklere sahip olduğu sonucuna ulaşmıştır.

Diğer taraftan; sosyal medyanın kaçınılmaz bir şekilde pazarlama iletişiminde bir paradigma değişimi yarattığı gerçeğini göz ardı etmemek gerekir. Sosyal medya, sadece diğer tüketici ya da markalarla etkileşime girme noktasında değil aynı zamanda kendi kullanıcı kaynaklı içeriğini (user-generated content/UGC) yaratma ve dolaşıma sokma noktasında da tüketicileri güçlendirmiştir. Bu da etkinin doğasının değişmesine yol açmıştır. Martensen ve diğerleri $(2018,335)$ bu geniş çevrimiçi takipçi tabanına sahip tüketicileri yeni nesil kanaat önderi olarak nitelemekte ve "vatandaş nüfuzlular" (citizen influencer) olarak tarif etmektedir.

$\mathrm{Bu}$ yeni nesil nüfuzlular yeri geldiğinde sosyal medya ünlüleri olarak adlandırılmakta ve geniş takipçi ağı bulunan, takipçileri üzerinde satınalmaya yönelik motivasyon gücü olan, içerik ürettiği alanda (örn. moda, güzellik, gezi, yemek, vb.) bilgi birikimine sahip olduğu düşünülen, tüketiciler için güvenilir bilgi kaynakları olarak algılanan bireylerdir.

Diğer bir deyişle, çevrimiçi nüfuzlu denildiğinde bir markayı hedef kitlesiyle bir araya getiren bir arkadaştan bahsedildiği düşünülebilir. Nüfuzlunun yarattığı marka odaklı içerikten etkilenen tüketici yalnızca kendisini getirmekle kalmaz, aynı zamanda takipçilerini de o içeriğin içine çekebilir. Bir sosyal medya nüfuzlusunun 
sadık takipçileri; markanın web sitesine trafik çekebilir, sosyal medya etkileşimini artırabilir ve kendi öneri veya hikayeleriyle markanın ürün veya hizmetinin reklamını yapabilir.

\subsection{Nüfuzlu (Influencer) Türleri}

Nüfuzlular hesaplarının bulunduğu sosyal medya platformuna göre (Instablogger, Youtuber, vb.) olduğu gibi takipçi sayılarına de göre kategorilere ayrılmaktadır:

\section{Mikro Nüfuzlu}

Niş bir hedef kitleye hitap eden, resmi bir sınıflandırma olmasa da 100.000 takipçi sayısının altında takipçisi olan nüfuzlular için kullanılan adlandırmadır (iAB Türkiye, 2018). Takipçi sayısı markalar tarafından önemli bir seçim kriteri olarak algılanıyor olsa da nüfuzlunun takipçilerini ürettiği içeriğe ne oranda dahil ettiği ve içerikle takipçi arasında yarattığı etkileşim (engagement) de ana performans kriterlerinden biri olarak kabul edilmektedir. Bu çerçeveden bakıldığında, mikro nüfuzluları diğerlerinden ayıran en önemli özelliğin takipçileri ile aralarındaki yüksek etkileşim olduğu düşünülmektedir. Mikro nüfuzlular yüksek takipçi sayılı makro nüfuzlulara göre daha erişilebilir ve ilişki kurulabilir olarak algılanmaktadır (Wissman, 2018).

\section{Makro Nüfuzlu}

Facebook, Instagram, Twitter, vb. sosyal iletişim ağlarında altı rakamdan daha büyük bir takipçi kitlesine sahip olan ve yayınladıkları içeriklerle yüksek etkileşim alan nüfuzlulardır (Mediakix, 2017). Makro nüfuzlular, sosyal iletişim ağlarında milyonlarca takipçi sayısı ile yaptıkları herhangi bir tanıtımı geniş kitlelerin görmesini sağlayan kişilerdir (Bones, 2017). Bu tanımlardan da anlaşılacağı üzere makro nüfuzluların markalar için en ayırt edici özellikleri marka mesajını yayma noktasındaki erişim gücü ve görünürlük yaratma avantajıdır (Hatton, 2018).

\subsection{Nüfuz Pazarlaması (Influencer Marketing) Stratejisi Olarak Ürün Yerleştirme}

McCracken'e (1989) göre bir ünlünün markaya olan katkısı o ünlünün sahip olduğu kültürel anlamların ilk önce ünlünün tanıtımını yaptığı markalı ürün ya da hizmete aktarılması oradan da o ürün ya da hizmeti satın alan tüketiciye taşınması ile ortaya çıkmaktadır. Anlam Transfer Modeli olarak adlandırılan bu yaklaşım ünlü kullanımı teorilerinin de temelini oluşturmaktadır. Bu anlamda pazarlamacılar; sosyal medyanın ortaya çıkıșıyla birlikte tüketicilerin hayatına giren yeni ünlü türü olarak nüfuzlular ile işbirliğine gittiklerinde aslında o nüfuzlunun (örn. Instablogger) sahip olduğu imaj ile özdeşleşmiş olan tüm kültürel anlamları ve özdeşlik ilişkilerini markalarına taşıma gayesini taşımaktadır. Bu noktada, marka imajı ile işbirliği yapılan nüfuzlunun imajı arasındaki uyum en kritik noktalardan biridir.

Marka ve nüfuzlu işbirlikleri farklı uygulama biçimleriyle karşımıza çıkmaktadır. iAB Türkiye (2018) markaların nüfuzlularla çalışma şekillerini 3 kategoride incelemektedir: (1) Ücretli, (2) ürün karşılığı ve (3) etkinliğe davet. Reklamveren nüfuzlu ile belirli bir paylaşım sayısı ve paylaşım başına ücret karşılığında "ücretli" işbirliğine gidebilir, yapılacak reklam kampanyası çerçevesinde nüfuzlulara ücretsiz markalı ürün gönderebilir ve bu ürünlerle ilgili nüfuzlunun içerik paylaşımı yapmasını teşvik edebilir ya da nüfuzluyu markanın düzenlediği bir etkinliğe davet ederek ücret karşılığı ya da gönüllü olarak bu davetle ilgili paylaşımda bulunmasını sağlayabilir. 
Bu ekonomik işbirliği modellerinin yanı sıra markalar nüfuzlularla farklı işbirliği stratejileri çerçevesinde çalışmalar yürütmektedir. Bu stratejiler ise markanın nüfuzlu ile işbirliğine giderken hangi iletişim hedefiyle (örn. farkındalık, etkileşim, satınalmaya yönlendirme, satış, tüketici sadakati) hareket ettiğine bağlı olarak şekillenmektedir (Content Marketing Institute, 2016). Ürün yerleștirme markaların söz konusu hedeflere ulaşmak için nüfuz pazarlaması çerçevesinde kullandığı etkin stratejilerden birisidir. Literatürde ürün yerleştirme genellikle sinema ve televizyon mecraları çerçevesinde incelenmiştir. Balasubramanian'a $(1994,31)$ göre ürün yerleștirme, "markalı bir ürünün sinema ve televizyon programlarının içine planlı ve göze çarpmayacak şekilde yerleştirmesiyle izleyiciyi etkilemeyi amaçlayan paralı ürün mesajlarıdır".

Dijital mecralar bağlamında değerlendirildiğinde ise, markalar ürün yerleștirmeyi bilgisayar oyunlarında, gazetelerin ve dergilerin web sitelerinde, Youtube, Instagram gibi yaratıcılığa dayalı sosyal ağlarda kullanmaktadır (Öztürk ve Şener, 2018). Russel ve Belch $(2005,74)$ ürün yerleştirmeyi günümüzdeki uygulamaları da kapsayacak şekilde "bir markanın belirli bir amaç doğrultusunda eğlence içeriği ile birleştirilmesi" olarak ele almaktadır. Ürün yerleştirme; "markanın editoryal içerik ile birleştirimesi" (van Reijmersdal ve diğerleri, 2007, 403) genel anlamda da "reklam alanı olarak nitelenmeyecek yerlerin içerisine markanın entegre edilmesi yoluyla tüketicilerin markalı içeriğe maruz bırakılmasıdır" (Wei ve diğerleri, 2008, 35).

Bu çalışmada ise, Instagram'da ürün yerleştirme markanın kullanıcıların ürettiği içerikle birleştirilmesi olarak tanımlanmaktadır. İçeriğin kullanıcının organik paylaşımlarını taklit ettiği; reklam mesajının, logonun veya marka karakterinin ürün paylaşım formatı içinde sunulduğu uygulamaları ifade etmektedir. Paylaşım amaçlı olsa dahi Instabloggerın organik paylaşımlarının görünüşünü ve hissiyatını vermektedir. Bu hikayeler sponsorların ve reklamverenlerin satışçı gibi görünmemesi için Instablogger'ın anlatı bütünlüğünü bozmamaya çabalamaktadır (Öztürk ve Şener, 2018).

\subsection{Nüfuz Pazarlaması ve Sosyal Medyada Ürün Yerleştirme Araştırmaları}

Sosyal medyada ürün yerleștirme yoluyla yapılan reklamlar yeni bir akademik araştırma alanı olması sebebiyle bulgular sınırlıdır. Liu ve diğerlerinin (2015) sosyal medyada ürün yerleştirme uygulamaları üzerine yaptıkları araștırma şu bulguları ortaya koymaktadır: (1) Video içerisinde örtük olarak yer verilen ürünler reklama yönelik tutumda ve tıklama niyetinde en çok etkiyi yaratan ürün yerleştirme biçimidir. Ancak, amaç farkındalık yaratmaksa pazarlamacılar videolarda görünür ürün yerleştirmeleri tercih etmelidir. (2) Sosyal medyada yapılan ürün yerleştirmelerde, ürün içeriğin anlatısıyla uyumlu biçimde entegre edildiğinde daha fazla etkiye sahip olmaktadır. Lynn ve diğerleri (2014) geleneksel mecralar ile dijital mecraları ürün yerleştirme bağlamında ayıran temel özelliğin interaktivite olduğunu belirtmektedir. Hang ve Auty (2011) interaktif video oyunlarının interaktif olmayanlara oranla ürün yerleştirme hatırlanırlığını daha fazla artırdığı sonucuna ulaşmıştır.

Ürün yerleştirmenin sosyal medya ile evrildiği nokta uygulamanın şu anda ne kadar esnek ve dinamik bir yapı kazandığını da ortaya koymaktır. Bu esnek ve dinamik yapının en görünür olduğu alanlardan biri de sosyal medya nüfuzlularının yaptığı ürün yerleştirme uygulamalarıdır. Birer tüketici olarak nüfuzluların yarattığı içeriklere entegre edilerek sunulan markalı ürünler kullanıcı-kaynaklı içerik ile 
reklam arasındaki sınırların giderek fluğlaştığı bir alan olarak karşımıza çıkmaktadır. Şener ve diğerleri (2016) Instabloggerların yaptıkları ürün yerleştirmelerin Instabloggerın algılanan güvenilirliğine etkide bulunduğunu ortaya koymuştur. Daha fazla interaktif unsur kullanılarak yapılan ürün yerleștirmelerin daha yüksek güvenilirlik algısına yol açtığı ve daha sık ürün yerleştirme yapan Instabloggerların daha düşük güvenilirlik skorlarına sahip olduğu gözlemlenmiştir. Kolcuoğlu (2018), nüfuzluların ulaşılabilir olmaları üzerinden bir samimiyet algısına sahip olduğunu ve samimi bulunan nüfuzluların içeriklerinde reklama yer vermelerinin takipçileri tarafından rahatsızlık verici bulunmadığını aksine bilgilendirici olarak değerlendirildiğini ortaya koymuştur. Nüfuzlunun denemediği ve güvenmediği markalı ürünleri ticari bir kaygıyla paylaşmasının etik bulunmadığı, nüfuzlu-takipçi ilişkisini zedelediği ve takipçilerde reklama yönelik negatif tutum oluşturduğu da aynı araștırmanın bulguları arasında yer almaktadır.

\section{Yöntem}

$\mathrm{Bu}$ çalışmanın amacı Instagram'da farklı kategorilerde (Moda, Gezi-Seyahat, Makyaj-Güzellik, Sağlık-Yaşam) hesapları bulunan nüfuzluların ürün yerleștirme uygulamalarında kullandıkları mesaj stratejilerini incelemektir. Mesaj stratejileri ve ürün yerleștirmeli içeriğin yarattığı etkileşim arasındaki ilişkinin araştırılması nüfuz pazarlaması bağlamında yürütülen yatırımın geri dönüşü (ROI) çalışmalarına da katkı sağlayacaktır.

\subsection{Araştırma Soruları (AS)}

Araştırmanın ana amacı çerçevesinde aşağıdaki sorulara yanıt aranmaktadır:

$\boldsymbol{A} \boldsymbol{S}_{\mathbf{1}}$ : Instagram'daki farklı hesap kategorilerinde (Moda, Gezi-Seyahat, MakyajGüzellik, Sağlık-Yaşam) içerik üreten Instabloggerların ürün yerleştirme uygulamalarının temel bileşenleri nelerdir?

$\boldsymbol{A S}_{2}$ : Instagramdaki farklı hesap kategorilerinde içerik üreten Instabloggerların yaptıkları ürün yerleştirmelerde kullandıkları mesaj stratejileri nelerdir?

$\boldsymbol{A S}_{\mathbf{3}}$ Instabloggerların yaptıkları ürün yerleștirmelerde kullandıkları farklı mesaj stratejileri, takipçi etkileşiminde anlamlı bir fark yaratmakta mıdır?

\subsection{Evren ve Örneklem}

Araştırmanın evrenini Instagram'da ürün yerleștirme yapan tüm Instabloggerlar oluşturmaktadır. Araştırma çerçevesinde; 4 farklı hesap kategorisinde (GeziSeyahat, Moda, Makyaj-Güzellik, Sağlık-Yaşam) hesapları bulunan 8 Makro Instablogger amaçlı örnekleme yöntemi temel alınarak belirlenmiştir. Amaçlı/ yargısal örneklemede "öğeler çalışma evreninden rastgele değil, belli özelliklerinden dolayı seçilirler" (Böke, 2011, 125). "Gerekli bilgiyi en iyi sağlayabilecek elemanların örnekleme seçilmesini içermektedir" (Özdemir, 2010, 95). Diğer bir deyişle, araştırmacının çalışmanın ilgilendiği anakitleyi en iyi temsil ettiğini düşündüğü elemanlar örneklemde yer almaktadır. Instabloggerlar takipçi sayıları bağlamında makro nüfuzlu kriterlerine uyup uymadıklarına ve paylaşımlarında ürün yerleștirme yapıp yapmadıklarına göre örnekleme dahil edilmişlerdir.

\subsection{Veri Toplama Araçları ve Teknikleri}

Araştırma kapsamında 1 Ocak 2018 - 28 Şubat 2018 tarihleri arasında örneklemi oluşturan 8 Instablogger'ın ürün yerleştirme uygulamalarını içeren 799 Instagram 
paylaşımı incelenmiş, kodlanmış ve içerik analizi uygulanmıştır. Instagram'da paylaşılan içerik; görsel (fotoğraf) ve metinsel olmak üzere iki temel bileşenden oluşmaktadır. Görsel bileşen ile kastedilen fotoğraf ve fotoğrafın içinde yer alan interaktivite unsurları (örn. tag, lokasyon), metinsel bileşen ise fotoğrafın altında yer alan metin ve interaktivite unsurlarıdır (örn. mention, hashtag, link). Bu çerçevede; analiz birimi makro Instabloggerın her bir Instagram paylaşımını oluşturan görsel ve metinsel bütün olarak belirlenmiştir. Bu araştırmanın dâhilinde, markalı ürünün Instagram paylaşımının görsel ya da metinsel içeriğinde yer aldığı her durum ürün yerleștirme olarak kabul edilmiștir.

\subsection{Kodlama Kategorileri ve Kodlayıcılar Arasındaki Güvenilirlik}

$\mathrm{Bu}$ çalışmada Öztürk ve diğerlerinin (2016) Instagram'da ürün yerleştirme uygulamalarına yönelik olarak geliştirdikleri kodlama cetveli temel alınmıştır. Bu cetvele ek olarak mesaj stratejilerinin belirlenmesi amacıyla Puto ve Wells'in (1984) ana mesaj stratejisi kategorileri, Laskey ve diğerlerinin (1989) alt mesaj stratejileri ve Taylor'un (1999) mesaj temaları kod cetveline eklenmiştir. Çalışmanın analiz birimi ürün yerleștirme yapılan Instagram paylaşımıdır.

Veri toplanırken iki kodlayıcı kullanılmıştır. Kodlayıcılar arasındaki güvenilirliği artırmak amacıyla kodlayıcılara kodlama kategorilerinin içeriği ve anlamı açıklanmıştır. Daha sonra, kodlayıcılardan örnekleme dahil olmayan ve ürün yerleştirme içeren 15 Instagram paylaşımını kodlamaları istenmiştir. Bu şekilde, kodlama formu ön teste tabi tutulmuştur. Ön-test sonuçlarına göre kodlama formunda gerekli görülen düzeltmeler yapılmıştır. Daha sonra kodlayıcılara, Instagram hesaplarını inceleyecekleri Instabloggerlar ve hangi tarih aralığındaki Instagram paylaşımlarını inceleyecekleri bilgisi verilmiştir.

Kodlayıcılar arasındaki geçerlilik düzeyi 2 ve daha fazla kodlayıcı için nominal datanın test edilmesinde kullanılan Krippendorff's Alpha değeri üzerinden hesaplanmıștır. Krippendorff (2004) iyi bir KALPHA değerini $\alpha \geq 0.800$ olarak, $0.800>\alpha \geq 0.667$ arasındaki değeri kabul edilebilir olarak, $\alpha<0.667$ değerleri ise kabul edilmemesi gereken değerler olarak belirtmektedir. 2 kodlayıcının kodlayıcılar arası geçerlilik düzeyi $(\alpha=0,892)$ yüksektir.

\subsection{Verilerin Analizi}

Çalıșmanın amacına uygun olarak temel araştırma sorularına cevap vermek üzere yapılan tanımlayıcı istatistikler, çapraz tablolar ve T-Test analizleri IBM SPSS Statistics 20 programı kullanılarak oluşturulmuştur.

\section{Bulgular}

Tablo 2'de görüldüğü üzere belirli zaman aralığında incelenen ürün yerleştirmeli paylaşımların yarısından fazlası $(\% 63,1)$ moda kategorisine aittir, onu makyaj/güzellik kategorisi (\%17) takip etmektedir. 
Tablo 2: Instabloggerın Hesap Kategorisine Dair Betimleyici İstatistik

\begin{tabular}{|l|l|c|c|}
\hline & & $\mathbf{N}$ & $\mathbf{\%}$ \\
\hline \multirow{4}{*}{$\begin{array}{l}\text { Instablogger } \\
\text { Hesap } \\
\text { Kategorisi }\end{array}$} & Moda & 504 & 63,1 \\
\cline { 2 - 4 } & Makyaj/Güzellik & 136 & 17,0 \\
\cline { 2 - 4 } & Sağlık/Yaşam & 86 & 10,8 \\
\cline { 2 - 4 } & Gezi & 73 & 9,1 \\
\cline { 2 - 4 } & Toplam & $\mathbf{7 9 9}$ & $\mathbf{1 0 0 , 0}$ \\
\hline
\end{tabular}

Yapılan ürün yerleştirmelerin yarısından fazlası $(\% 63,2)$ giyim/ayakkabı/aksesuar ürün kategorisine aittir. Bunu medya ve eğlence $(\% 9,9)$ ve kișisel bakım $(\% 6,5)$ kategorileri takip etmektedir (Tablo 3).

Tablo 3: Ürün Yerleștirmenin Yapıldı̆̆ı Ürün Kategorilerine Dair Betimleyici İstatistik

\begin{tabular}{|l|l|c|c|}
\hline & & N & \% \\
\hline \multirow{4}{*}{ Ürün Kategorisi } & Giyim/Ayakkabı/Aksesuar & 505 & 63,2 \\
\cline { 2 - 4 } & Medya ve Eğlence & 79 & 9,9 \\
\cline { 2 - 4 } & Kişisel Bakım & 52 & 6,5 \\
\cline { 2 - 4 } & Dinlenme/Eğlence/Spor & 41 & 5,1 \\
\cline { 2 - 4 } & Diğer & 122 & 15,3 \\
\cline { 2 - 4 } & Toplam & $\mathbf{7 9 9}$ & $\mathbf{1 0 0 , 0}$ \\
\hline
\end{tabular}

Tablo 4'e göre ürün yerleştirmelerin büyük çoğunluğunun $(\% 82,4)$ görsel biçimde yapıldı̆̆ı görülmektedir.

Tablo 4: Ürün Yerleștirmenin Yapıldı̆̆ı Ürün Kategorilerine Dair Betimleyici İstatistik

\begin{tabular}{|c|c|c|c|}
\hline & & N & $\%$ \\
\hline \multirow{5}{*}{$\begin{array}{l}\text { Ürün } \\
\text { Yerleştirme } \\
\text { Biçimi }\end{array}$} & Görsel & 658 & 82,4 \\
\hline & Metin & 106 & 13,3 \\
\hline & Sesli Video & 34 & 4,3 \\
\hline & Sessiz Video & 1 & 0,1 \\
\hline & Toplam & 799 & 100,0 \\
\hline
\end{tabular}

Instabloggerların ürün yerleştirme yaptıkları markaların kökenine bakıldığında yarısından fazlasını (\%52,9) yabancı markalar, \%38,3'ünü yerli markalar, geri kalanını $(\% 8,8)$ ise Instablogger'ın kendisinin yarattığı bireysel markası oluşturmaktadır (Tablo 5).

Tablo 5: Marka Kökenine Dair Betimleyici İstatistik

\begin{tabular}{|l|l|c|c|}
\hline & & N & \% \\
\hline \multirow{4}{*}{ Marka Kökeni } & Yabancı & 423 & 52,9 \\
\cline { 2 - 4 } & Yerli & 306 & 38,3 \\
\cline { 2 - 4 } & Kendi Markası & 70 & 8,8 \\
\cline { 2 - 4 } & Toplam & $\mathbf{7 9 9}$ & $\mathbf{1 0 0 , 0}$ \\
\hline
\end{tabular}

Yapılan ürün yerleștirmelerin \%71.1'ini düşük ilginlik düzeyine sahip markalı ürünler oluşturmaktadır (Tablo 6). İlginlik düzeyi bir markalı ürünü tüketme noktasında tüketicinin o ürüne ne kadar önem atfettiği ve ilgi duyduğunu ifade etmektedir. Ürün ilginliği belirli bir ürün kategorisinin önemine dair tüketicinin 
sahip olduğu algıyı tanımlamaktadır ve bu algı tüketicinin ihtiyaçları, değerleri ve ilgi alanları ile şekillenmektedir (Zaichkowsky, 1985, 342). Yüksek ilginlikli ürünler uzun ve dikkatli bir değerlendirme süreci sonucunda satın alınan ürünlerdir. Diğer taraftan, düşük ilginlikli ürünler satın alma öncesinde çok karmaşık olmayan karar süreçlerini ve düşük satın alma riski içeren ürünlerdir (Handriana ve Wisandiko, 2017, 293).

Tablo 6: Ürünün İlginlik Düzeyine Dair Betimleyici İstatistik

\begin{tabular}{|l|l|c|c|}
\hline & & N & $\%$ \\
\hline \multirow{3}{*}{ Illginlik Düzeyi } & Düşük & 568 & 71,1 \\
\cline { 2 - 4 } & Yüksek & 231 & 28,9 \\
\cline { 2 - 4 } & Toplam & $\mathbf{7 9 9}$ & $\mathbf{1 0 0 , 0}$ \\
\hline
\end{tabular}

Yapılan yerleştirmelerde markalı ürün ağırlıklı olarak arka planda $(\% 82,6)$ yer almaktadır (Tablo 7) ve uzak çekimle $(\% 83,1)$ gösterilmiştir (Tablo 8). Benzer şekilde; yerleştirilen ürünler görüntünün merkezinde yer almamaktadır (\%84.1) (Tablo 9).

Tablo 7: Ürün Yerleștirmelerinin Görsel İçindeki Yerlerine Dair Betimleyici İstatistik

\begin{tabular}{|l|l|c|c|}
\hline & & N & $\%$ \\
\hline \multirow{3}{*}{$\begin{array}{l}\text { Görsel } \\
\text { İindeki Yer }\end{array}$} & Arka Plan & 660 & 82,6 \\
\cline { 2 - 4 } & Ön Plan & 139 & 17,4 \\
\cline { 2 - 4 } & Toplam & $\mathbf{7 9 9}$ & $\mathbf{1 0 0 , 0}$ \\
\hline
\end{tabular}

Tablo 8: Ürün Yerleștirmenin Görünürlüğüne Dair Betimleyici İstatistik

\begin{tabular}{|l|l|c|c|}
\hline & & N & \% \\
\hline \multirow{4}{*}{ Görünürlük } & Uzak Çekim & 664 & 83,1 \\
\cline { 2 - 4 } & Yakın Çekim & 135 & 16,9 \\
\cline { 2 - 4 } & Toplam & $\mathbf{7 9 9}$ & $\mathbf{1 0 0 , 0}$ \\
\hline
\end{tabular}

Tablo 9: Ürünlerin Kamera Açısına Dair Betimleyici İstatistik

\begin{tabular}{|l|l|c|c|}
\hline & & N & \% \\
\hline \multirow{3}{*}{ Kamera Açısı } & Ürün Merkezde Değil & 672 & 84,1 \\
\cline { 2 - 4 } & Ürün Merkezde & 127 & 15,9 \\
\cline { 2 - 4 } & Toplam & $\mathbf{7 9 9}$ & $\mathbf{1 0 0 , 0}$ \\
\hline
\end{tabular}

Yerleştirme yapılan ürünlerin çoğunlukla ürün/paket (\%70) olarak sergilendiği, onu reklam $(\% 18,4)$ ve metin $(\% 11,6)$ biçimindeki yerleştirmelerin takip ettiği görülmektedir (Tablo 10).

Tablo 10: Ürünün Sergilenme Biçimine Dair Betimleyici İstatistik

\begin{tabular}{|l|l|c|c|}
\hline & & N & \% \\
\hline \multirow{3}{*}{$\begin{array}{l}\text { Ürünün } \\
\text { Sergileme } \\
\text { Biçimi }\end{array}$} & Ürün/Paket & 559 & 70,0 \\
\cline { 2 - 4 } & Reklam & 147 & 18,4 \\
\cline { 2 - 4 } & Metin & 93 & 11,6 \\
\cline { 2 - 4 } & Toplam & $\mathbf{7 9 9}$ & $\mathbf{1 0 0 , 0}$ \\
\hline
\end{tabular}

Ürün yerleştirmelerin neredeyse tamamında $(\% 93,7)$ Instablogger ürünle etkileşim halindedir (Tablo 11). 
Tablo 11: Instablogger-Ürün Etkileșimine Dair Betimleyici İstatistik

\begin{tabular}{|l|l|c|c|}
\hline & & N & \% \\
\hline \multirow{3}{*}{$\begin{array}{l}\text { Instablogger } \\
\text { Ürün Etkileşimi }\end{array}$} & Instablogger & 749 & 93,7 \\
\cline { 2 - 4 } & Hiçkimse & 50 & 6,3 \\
\cline { 2 - 4 } & Toplam & $\mathbf{7 9 9}$ & $\mathbf{1 0 0 , 0}$ \\
\hline
\end{tabular}

Yapılan yerleştirmede yer alan markalı ürün ile hesap kategorisi arasındaki uyum incelendiğinde çoğunlukla hesabın kategorisiyle uyumlu $(\% 68,7)$ ürünler olduğu (örn. gezi-seyahat ve fotoğraf makinesi) ortaya çıkmıştır (Tablo 12).

Tablo 12: Instagram Hesabı ile Ürün Kategorisinin Uyumuna Dair Betimleyici İstatistik

\begin{tabular}{|l|l|c|c|}
\hline & & N & \% \\
\hline \multirow{2}{*}{$\begin{array}{l}\text { Instagram } \\
\text { Hesabı-Ürün } \\
\text { Uyumu }\end{array}$} & Uyumlu & 549 & 68,7 \\
\cline { 2 - 4 } & Uyumsuz & 250 & 31,1 \\
\cline { 2 - 4 } & Toplam & $\mathbf{7 9 9}$ & $\mathbf{1 0 0 , 0}$ \\
\hline
\end{tabular}

Ürün yerleştirme paylaşımlarındaki hikaye içeriği incelendiğinde markalı ürünlerin sadece \%6.9'unun bir hikayenin parçası olarak yerleștirildiğini, paylaşımların çok yüksek oranda herhangi bir hikaye içermediği $(\% 85,2)$ görülmektedir (Tablo 13).

Tablo 13: Ürün-Hikaye Entegrasyonuna Dair Betimleyici İstatistik

\begin{tabular}{|l|l|c|c|}
\hline & & $\mathbf{N}$ & $\mathbf{1}$ \\
\hline \multirow{4}{*}{$\begin{array}{l}\text { Ürün-Hikaye } \\
\text { Entegrasyonu }\end{array}$} & Hikaye Yok & 681 & 85,2 \\
\cline { 2 - 4 } & Düşük & 63 & 7,9 \\
\cline { 2 - 4 } & Yüksek & 55 & 6,9 \\
\cline { 2 - 4 } & Toplam & $\mathbf{7 9 9}$ & $\mathbf{1 0 0 , 0}$ \\
\hline
\end{tabular}

Instabloggerların yaptıkları ürün yerleştirmeli paylaşımlarda ortaya koydukları mesaj stratejilerine bakıldığında \%86,7'sının transformasyonel (dönüşümsel) mesaj stratejisi içerdiği bulgulanmıştır (Tablo 14).

Tablo 14: Ürün Yerleștirmeli Paylaşımlardaki Ana Mesaj Stratejileri Betimleyici İstatistik

\begin{tabular}{|l|l|c|c|}
\hline & & N & \% \\
\hline \multirow{3}{*}{$\begin{array}{l}\text { Ana Mesaj } \\
\text { Stratejisi }\end{array}$} & Transformasyonel (Dönüşümsel) & 693 & 86,7 \\
\cline { 2 - 4 } & Bilgisel & 106 & 13,3 \\
\cline { 2 - 4 } & Toplam & $\mathbf{7 9 9}$ & $\mathbf{1 0 0 , 0}$ \\
\hline
\end{tabular}

Instabloggerların ürün yerleştirmeli paylaşımlarında kullandıkları ana mesaj stratejilerinin alt kırılımlarına bakıldığında (Tablo 15);

- En yoğun kullanılan alt strateji transformasyonel mesaj türlerinden "kullanım anı"dır (\%70,3). Kullanım anı stratejisi mesajda kullanım deneyiminin tüketiciye gösterilmesini içerir. Böylece ürünün kullanım alanlarının genişletilmesi amaçlanır.

- Kullanım anını yine transformasyonel mesaj türlerinden marka imajı $(\% 9,9)$ ve bilgisel mesaj türlerinden jenerik/bilgisel $(\% 9,3)$ mesaj stratejileri takip etmektedir. 
Tablo 15: Ürün Yerleștirmeli Paylaşımlardaki Ana Mesaj

Stratejilerinin Alt Türleri Betimleyici İstatistik

\begin{tabular}{|l|l|l|c|c|}
\hline & & & N & $\%$ \\
\hline \multirow{4}{*}{$\begin{array}{l}\text { Ana Mesaj } \\
\text { Stratejisinin } \\
\text { Türü }\end{array}$} & \multirow{3}{*}{$\begin{array}{l}\text { Transformasyonel } \\
\text { (Dönüşümsel) }\end{array}$} & Kullanım Anı & 562 & 70,3 \\
\cline { 3 - 5 } & \multirow{3}{*}{ Bilgisel } & Marka İmajı & 79 & 9,9 \\
\cline { 3 - 5 } & & $\begin{array}{l}\text { Jenerik/Transformasyonel } \\
\text { (Dönüşümsel) }\end{array}$ & 38 & 4,8 \\
\cline { 2 - 5 } & Jenerik/Bilgisel & 74 & 9,3 \\
\cline { 2 - 5 } & Biricik Satış Önermesi & 32 & 4,0 \\
\cline { 2 - 5 } & Kullanıcı İmajı & 14 & 1,8 \\
\hline & Toplam & $\mathbf{7 9 9}$ & $\mathbf{1 0 0 , 0}$ \\
\hline
\end{tabular}

Tablo 16'nın ortaya koyduğu üzere en sık kullanılan mesaj teması iletişimi kültürel anlamları örgütlemenin bir aracı olarak gören ritüel temelli yaklaşımın alt temalarından olan egodur $(\% 76,6)$. Ego temasında tüketicinin ya da Instablogger'ın olduğu ya da olmak istediği kişi ile ilgili algısına yönelik mesaj çekicilikleri kullanılmaktadır. "Bireyin başkaları tarafından farkedilme ve saygı duyulma ihtiyacının tüketilen ürünler üzerinden karşılanmasını" (Golan ve Zaidner, 2008, 964) öngörür. Çok sınırlı düzeyde ya da hiç rasyonel bilgi vermeden imaj odaklı iletişim yapılır. Ego temasını yine ritüel temelli iletişimin yaklaşımının alt temalarından olan sosyal $(\% 10,1)$ ve iletişimin "iletim" işlevini yansıtan rutin $(\% 9,4)$ temalarına sahip mesajlar takip etmektedir. Sosyal temasında markalı ürün sosyal bir bağlamın parçası olarak (örn. anneler günü) resmedilirken rutin temasında ürünün tüketicinin rutini içerisindeki rolü vurgulanmaktadır.

Tablo 16: Ürün Yerleștirmeli Paylaşımlardaki Mesaj Temaları Betimleyici İstatistik

\begin{tabular}{|l|l|c|c|}
\hline & & N & \% \\
\hline \multirow{4}{*}{$\begin{array}{l}\text { Mesaj } \\
\text { Temaları }\end{array}$} & $\begin{array}{l}\text { Ego } \\
\text { (Transformasyonel) }\end{array}$ & 612 & 76,6 \\
\cline { 2 - 4 } & $\begin{array}{l}\text { Sosyal } \\
\text { (Transformasyonel) }\end{array}$ & 81 & 10,1 \\
\cline { 2 - 4 } & Rutin (Bilgisel) & 75 & 9,4 \\
\cline { 2 - 4 } & Rasyonel (Bilgisel) & 31 & 3,9 \\
\cline { 2 - 4 } & Toplam & $\mathbf{7 9 9}$ & $\mathbf{1 0 0 , 0}$ \\
\hline
\end{tabular}

Instabloggerın hesap kategorisi ile kullandığı ana mesaj stratejisi arasındaki ilişki incelendiğinde şu sonuçlara ulaşılmıştır (Tablo 17);

- Gezi $(\% 68,5)$ ve Sağlı/Yaşam $(\% 64,7)$ kategorilerinde hesapları bulunan ve ürün yerleştirmeli paylaşım yapan Instabloggerlar, takipçilerine (tüketiciler) markalı ürün bilgisi verirken çoğunlukla transformasyonel (dönüşümsel) duygulara seslenen - mesaj stratejilerine başvurmaktadır.

- Bu durum Moda $(\% 91,5)$ ve Makyaj/Güzellik $(\% 91,2)$ kategorilerindeki ürün yerleştirmeli paylaşımların neredeyse tamamı için geçerlidir.

- Instagram hesabının kategorisi ve ana mesaj stratejisi arasındaki ilişkinin gücüne bakıldığında ise düşük olduğu bulgulanmıştır (Cramer's V katsayısı $\leq 0,30)$. 2x2'den büyük tablolarda etki gücü Phi katsayısı değil Cramer's V değeri üzerinden değerlendirilmektedir. Pallant'a $(2010,220)$ göre etki gücü kriterleri şu şekilde sıralanmaktadır: Düşük: 0.01, Orta: 0.30, Yüksek: 0.50 
Toblo 17: Hesap Kategorisine Göre Ana Mesaj Stratejilerinin Dă̆llımı

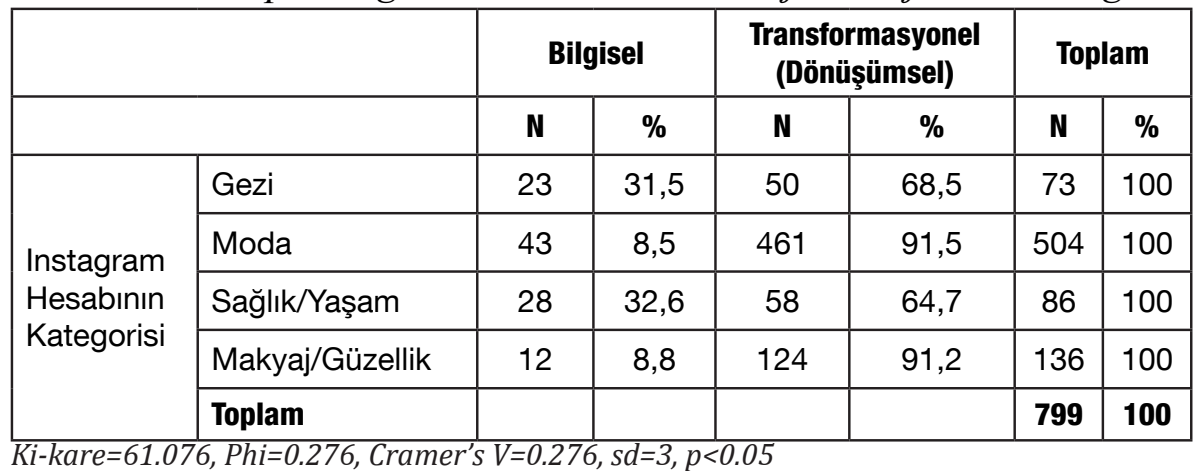

Ana mesaj stratejisi ile mesaj stratejisinin alt türü arasındaki ilişkiye bakıldığında ise (Tablo 18),

- Instabloggerların yaptıkları ürün yerleştirmelerde bilgisel mesaj kullandıkları durumların \%69,8'inde jenerik/bilgisel stratejiyi tercih ettikleri görülmektedir. Diğer bir deyişle, Instabloggerlar çoğunlukla markalı ürün ile ilgili mesaj vermek yerine ürün kategorisine vurgu yapmayı tercih etmektedir. Bilgisel mesaj içeren ürün yerleştirmelerin sadece üçte birinde $(\% 30,2)$ markalı ürününü farklılaştıran bir özellik öne çıkarılarak biricik satış önermesi stratejisi izlenmiştir.

- Instabloggerların yaptıkları ürün yerleștirmelerde transformasyonel (dönüşümsel) mesaj kullandıkları durumların \%81,1'inde kullanım anını vurguladıkları bulgulanmıștır. Onu marka imajı odaklı mesaj stratejileri $(\% 11,4)$ takip etmektedir.

- Ana mesaj stratejisi ile alt türü arasındaki ilişkinin gücüne bakıldığında ise çok

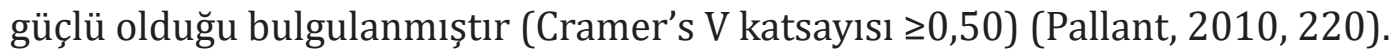

Tablo 18: Ana Mesaj Stratejilerine Göre Mesaj Stratejisinin Alt Türünün Dağılımı

\begin{tabular}{|c|c|c|c|c|c|}
\hline Ana Mesaj Stratejisi & Mesaj Stratejisinin Alt Türü & $\mathbf{N}$ & $\%$ & $\mathbf{N}$ & $\%$ \\
\hline \multirow{3}{*}{ Bilgisel } & Jenerik/Bilgisel & 74 & 69,8 & & \\
\hline & Biricik Satış Önermesi & 32 & 30,2 & & \\
\hline & Toplam & 106 & 100 & & \\
\hline \multirow{5}{*}{$\begin{array}{l}\text { Transformasyonel } \\
\text { (Dönüşümsel) }\end{array}$} & Kullanım Anı & & & 562 & 81,1 \\
\hline & Marka İmajı & & & 79 & 11,4 \\
\hline & $\begin{array}{l}\text { Jenerik/Transformasyonel } \\
\text { (Dönüşümsel) }\end{array}$ & & & 38 & 5,5 \\
\hline & Kullanıcı İmajı & & & 14 & 2 \\
\hline & Toplam & & & 693 & 100 \\
\hline
\end{tabular}

Ana mesaj stratejisi ile mesaj temaları arasındaki ilişkiye bakıldığında şu sonuçlara varılmıştır (Tablo 19);

- Instabloggerların bilgisel mesaj stratejisi kullandıkları ürün yerleștirmeli paylaşımların \%70,8'sinde markalı ürün "rutin" teması çerçevesinde tüketiciye sunulmaktadır. Geri kalan \%29,2'sinde ise tüketicinin ürünle ilgili bilgi ihtiyacını karşılama ve verilen bilgi üzerinden ikna etme çabasını yansıtan "rasyonel" mesaj teması gözlemlenmektedir. 
- Instabloggerların transformasyonel (dönüşümsel) mesaj stratejisi kullandıkları ürün yerleştirmeli paylaşımların \%88,3'ü tüketicilerin oldukları ya da olmak istedikleri kişiye gönderme yapan "ego" teması çerçevesinde gerçekleştirilmiştir. Paylaşımların \%11,7'sinin ise markalı ürün tüketiminin belirli bir sosyal bağlam (örn. anneler günü) çerçevesinde resmedildiği ve bireysel tüketimden ziyade kolektif tüketimin öne çıkartıldığı "sosyal" mesaj temasına sahip olduğu tespit edilmiştir.

- Ana mesaj stratejisi ile mesaj temaları arasındaki ilişkinin gücüne bakıldığında ise çok güçlü olduğu bulgulanmıştır (Cramer's V katsayısı $\geq 0,50$ ) (Pallant, 2010, 220).

Tablo 19: Ana Mesaj Stratejisine Göre Mesaj Temaları Dağılımı

\begin{tabular}{|c|c|c|c|c|c|c|c|c|c|c|c|}
\hline & & \multicolumn{2}{|c|}{ Rasyonel } & \multicolumn{2}{|c|}{ Rutin } & \multicolumn{2}{|c|}{ Ego } & \multicolumn{2}{|c|}{ Sosyal } & \multicolumn{2}{|c|}{ Toplam } \\
\hline & & $\mathbf{N}$ & $\%$ & $\mathbf{N}$ & $\%$ & N & $\%$ & $\mathbf{N}$ & $\%$ & N & $\%$ \\
\hline \multirow{2}{*}{$\begin{array}{l}\text { Ana } \\
\text { Mesaj } \\
\text { Stratejisi }\end{array}$} & Bilgisel & 31 & 29,2 & 75 & 70,8 & & & & & 106 & 100 \\
\hline & $\begin{array}{l}\text { Transformasyonel } \\
\text { (Dönüşümsel) }\end{array}$ & & & & & 612 & 88,3 & 81 & 11,7 & 693 & 100 \\
\hline
\end{tabular}

Tablo 20'de çalışmanın bir diğer eksenini oluşturan ana mesaj stratejisi ile interaktif unsur sayısı, beğeni sayısı, takipçi yorum sayısı ve Instabloggerın yorum sayısı arasındaki ilişkiye dair T-Test sonuçları sunulmuştur. T-Test parametrik analiz tekniklerinden biridir ve "örneklemin geldiği evrende söz konusu değişkenin normal dağıldığı" varsayımına dayanmaktadır (Healey, 2015, 153). Sosyal bilimler alanındaki birçok araştırmada bağımlı değișken skorlarının normal dağılmadığı durumlarla karşılaşılmaktadır. Ancak, büyük örneklemle çalışılması durumunda $(n \geq 100)$ örneklemde bulunan her bir grup için skor dağılımlarının normal olduğu varsayılmaktadır (Healey, 2015). Bu çalışmada T-Test analizine dahil edilen örneklemin büyüklüğü her bir grup için belirtilen kriteri karşılar niteliktedir (Bilgisel Mesaj (n)=106>n=100, Transformasyonel Mesaj (n)=693>n=100).

Analiz sonucundaki bulgular şu şekildedir;

- Ana mesaj stratejisine göre ürün yerleştirmeli paylaşımdaki interaktif unsur ortalamalarının anlamlı şekilde farklılaştığı görülmektedir $(p<0,05)$. Instabloggerlar bilgisel mesaj stratejisi kullandıkları Instagram paylaşımlarında dönüşümsel mesaj kullandıkları Instagram paylaşımlarına göre $(\overline{\mathrm{x}}=1,27)$ daha fazla interaktif unsur $(\overline{\mathrm{x}}=1,76)$ kullanmaktadır $\left(\mathrm{Eta}^{2}=0,187\right)$.

- Ana mesaj stratejisine göre beğeni sayısı ortalamalarının anlamlı biçimde farklılașmadığı görülmüștür ( $p>0,05)$.

- Ana mesaj stratejisine göre takipçilerin yorum sayısı ortalamalarının anlamlı biçimde farklılaştığı bulgulanmıştır $(\mathrm{p}<0,05)$. Bilgisel mesajların $(\bar{x}=330,47)$ dönüşümsel mesajlara $(\bar{x}=104,70)$ göre daha fazla takipçi yorumu aldığı görülmektedir.

- Ana mesaj stratejisine göre Instabloggerın yorum ortalamasının anlamlı biçimde farklılaşmadığı bulgulanmıştır ( $\mathrm{p}>0,05)$. 
Tablo 20: Ana Mesaj Stratejisi Bağlamında İnteraktif Unsur Sayısı, Beğeni Sayısı, Takipçi Sayısı ve Instabloggerın Yorum Sayısını Açıklayan T-Test Analiz Sonuçları

\begin{tabular}{|c|c|c|c|c|c|c|c|c|}
\hline & $\begin{array}{l}\text { Ana Mesaj } \\
\text { Stratejisi }\end{array}$ & $\mathbf{N}$ & Ortalama & SS & $\mathbf{F}$ & $\mathbf{t}$ & $\mathbf{P}$ & Eta2 \\
\hline \multirow{2}{*}{$\begin{array}{l}\text { interaktif } \\
\text { Unsur Sayısı }\end{array}$} & Bilgisel & 106 & 1,76 & 0,787 & \multirow{2}{*}{32,580} & \multirow{2}{*}{6,227} & \multirow{2}{*}{0,000} & \multirow{2}{*}{0,187} \\
\hline & $\begin{array}{l}\text { Transformasyonel } \\
\text { (Dönüşümsel) }\end{array}$ & 693 & 1,27 & 0,512 & & & & \\
\hline \multirow{2}{*}{ Beğeni Sayısı } & Bilgisel & 106 & 17782,85 & 22682,177 & \multirow{2}{*}{0,501} & \multirow{2}{*}{0,168} & \multirow{2}{*}{0,866} & \multirow{2}{*}{ - } \\
\hline & $\begin{array}{l}\text { Transformasyonel } \\
\text { (Dönüşümsel) }\end{array}$ & 693 & 17379,53 & 23041,408 & & & & \\
\hline \multirow{2}{*}{$\begin{array}{l}\text { Takipçi Yorum } \\
\text { Sayısı }\end{array}$} & Bilgisel & 106 & 330,47 & 1004,224 & \multirow{2}{*}{82,238} & \multirow{2}{*}{2,308} & \multirow{2}{*}{0,023} & \multirow{2}{*}{0,435} \\
\hline & $\begin{array}{l}\text { Transformasyonel } \\
\text { (Dönüşümsel) }\end{array}$ & 693 & 104,70 & 198,574 & & & & \\
\hline \multirow{2}{*}{$\begin{array}{l}\text { Instabloggerın } \\
\text { Yorum Sayısı }\end{array}$} & Bilgisel & 106 & 6,08 & 11,287 & \multirow{2}{*}{0,515} & \multirow{2}{*}{$-0,106$} & \multirow{2}{*}{0,916} & \multirow{2}{*}{ - } \\
\hline & $\begin{array}{l}\text { Transformasyonel } \\
\text { (Dönüšümsel) }\end{array}$ & 693 & 6,23 & 13,504 & & & & \\
\hline
\end{tabular}

\section{Sonuç ve Değerlendirme}

Geçtiğimiz on yıllık dönemde; sosyal medyanın parçalara ayrılarak çoğalması ve çeşitlenmesinin reklam üzerindeki etkisi devam etmektedir. Bunun önemli bir sebebi, tüketicilerin ister tanıdıkları insanlardan isterse tanımadıkları sosyal medya kişiliklerinden (örn. Instablogger ya da Youtuber) elektronik ağızdan ağıza (eWOM) yoluyla aldıkları bilgiye olan güvenlerinin giderek artmasıdır (Sheth, 2018, 7). Bu anlamda sosyal medya nüfuzluları; "bloglar, tweetler ve diğer sosyal medya araçları yardımıyla tüketicilerin tutumlarını şekillendiren" (Freberg ve diğerleri, 2011, 90) yeniçağın içerik küratörleri ve kanaat önderleri olarak değerlendirilmektedir. Hal böyleyken, bu yeni nesil kanaat önderleri pazarlamacılar için birer cazibe merkezi haline gelmiştir.

$\mathrm{Bu}$ çalışmanın amacı; bir elektronik ağızdan ağıza iletişim yöntemi olarak değerlendirilen Nüfuz Pazarlaması'nda kullanılan mesaj stratejilerini farklı hesap kategorilerinde (moda, makyaj/güzellik, gezi/seyahat, sağlık/yaşam) içerik üreten makro Instabloggerların ürün yerleştirme uygulamaları üzerinden incelemektedir. Çalışma kapsamında, ürün yerleştirmenin temel bileşenlerinin yanı sıra mesaj stratejileri ile sosyal medyanın ayırt edici özelliği olarak etkileşim unsurları (örn. beğeni, tüketici ve Instablogger yorumu) arasındaki ilişki de irdelenmiştir.

Tafesse ve Wien $(2018,244)$ mesaj stratejilerini "pazarlamacıların söylemek istedikleriyle tüketicilerin duymak istedikleri arasındaki mesafeyi kapatmaya yarayan" yönlendirici kaideler olarak tanımlamaktadır. Makro Instabloggerlar yaptıkları ürün yerleştirmeli paylaşımların büyük çoğunluğunda tüketicilerin duygu 
ve duyularına seslenen transformasyonel (dönüşümsel) mesajlar kullanmaktadır. Bu sonuç, Instabloggerların yerleștirme yaptıkları markalı ürünlerin ağırlıklı düşük ilginlikli (\%71) olmasıyla da örtüșen bir durumu yansıtmaktadır. Düşük ilginlikli ürünler; tüketicinin çok karmaşık olmayan bir bilişsel süreçten geçerek satın aldığl, görece düşük fiyatlı ve yanlış ürün satın alınması durumunda tüketici için yüksek bir risk arzetmeyen ürünlerdir. Hal böyleyken, Instabloggerların markaları entegre ettikleri paylaşımlarında rasyonel argümanlardansa duygu çekicilikleri kullanmaları ve imaj odaklı bir mesaj stratejisi belirlemeleri tutarlı bir pazarlama yaklaşımıdır.

Yapılan ürün yerleștirmelerde kullanılan ana mesaj stratejilerinin alt kırılımlarına bakıldığında yoğun olarak transformasyonel (dönüşümsel) mesaj stratejilerinin alt türü olan "kullanım anı"nın (\%70) kullanıldığı görülmektedir. Bu stratejinin kullanıldığı paylaşımlar ürünün yeni bir kullanım biçiminin tanıtıldığı ya da kullanım deneyiminin tüketiciye gösterilmesinin hedeflendiği mesajlar içermektedir (Laskey ve diğerleri, 1989). Instabloggerlar, takipçileri gibi normal hayatlara sahip bireyler olarak sosyal medyada varolduğuna gönderme yapar biçimde "vatandaş nüfuzlu" (Martensen ve diğerleri, 2018) olarak da tanımlanmaktadır. Araștırmanın da işaret ettiği üzere; paylaşımlarının çoğunda kendi hayat hikayelerinin akışı içerisinde ürünü nasıl deneyimlediklerine ve tüketicilerin de ürünü kendi hayatlarına nasıl dahil edebileceklerine dair bilgi paylașımı yapmaktadırlar. Tafesse ve Wien $(2017,10)$ sosyal medyadaki bu tür paylaşımları "kişisel marka paylaşımları" olarak nitelemektedir.

Mesaj temaları bazında değerlendirildiğinde ise; Instabloggerların en çok "ego" temelli ve onu takip eden "sosyal" temalı mesaj stratejileri kullandıkları tespit edilmiştir. "Ego" temasındaki mesajlar tüketicilerin benlik tanımlarına ve kendini gerçekleştirme ihtiyacına yönelik çekiciliklerin (örn. olabileceğinin en iyisi ol) kullanıldığı içerikleri ifade etmektedir. "Sosyal" temalı paylaşımlar ise tüketicileri motive edici sosyal ortamların resmedildiği mesajları içermektedir. Bu çerçeveden değerlendirildiğinde; Instabloggerlar yaptıkları yerleştirmelerde markalı ürünü ya tüketicinin imaj inşasının bir aracı olarak ya da tüketiciyi sosyal bir grup ya da durumun parçası haline getirecek bir firsat olarak sunmaktadır. "Ego" temasında yerleştirme yaptıkları ürünün tam da takipçileri için olduğunun altını çizerken (Taylor, 1999, 13), "sosyal” temasında takipçilerin çevrelerine ve çevrelerinin onlarla ilgili düşüncelerini dönüștürmeye odaklanmaktadır.

Ana mesaj stratejilerinin (bilgisel ve transformasyonel) her biri bazında hangi alt mesaj stratejileri ve mesaj temalarının ağırlıklı kullanıldığına bakıldığında;

- Instabloggerların bilgisel mesaj stratejisi kullandıkları ürün yerleştirmeli paylaşımlarda ağırlıklı biçimde belirli bir markalı üründen ziyade ürün kategorisine gönderme yaptıkları "jenerik/bilgisel" mesajlar verdikleri tespit edilmiştir. Bunun bir sebebi, Instabloggerların belirli bir ürünü öne çıkararak yapılan yerleştirmenin ticariliğinin altını çizmemek olabilir. Çalışmanın bir diğer bulgusu da bilgisel mesaj stratejilerinde en çok "rutin" temasının Instabloggerlar tarafından hayata geçirildiğidir. Bu da şu anlama gelmektedir: Ürün yerleştirme uygulamasına yer verdikleri paylaşımların doğal algısını güçlendirmek adına Instabloggerlar, markalı ürünü daha çok günlük hayat rutinlerinin bir parçasıymış, düzenli kullandıkları bir markaymışçasına resmetmektedirler. 
- Instabloggerların transformasyonel mesaj stratejisi kullandıkları ürün yerleștirmeli paylaşımlarda ağırlıklı biçimde kullanım anına odaklandıkları ve

"ego" temalı mesajlarla ürünü tüketicilere anlattıkları görülmektedir.

Hesap türüne göre incelendiğinde; tüm hesap kategorilerindeki Instabloggerların ürün yerleştirme yaptıkları içeriklerde ağırlıklı transformasyonel (dönüşümsel) mesajlar kullandıkları görülmektedir. Bu durum; transformasyonel mesajların içerdikleri duygusal, sembolik ve hazcı marka ipuçları sebebiyle daha fazla tüketici etkileşimi yarattığı (Tafesse ve Wien, 2018, 250) düşünüldüğünde çok da şaşırtıcı değildir. Etkileşim nüfuz pazarlamasının en önemli performans kriterlerinden biri kabul edilmektedir. Diğer bir deyişle; nüfuzlunun pazarlamacılar tarafinda işbirliği için tercih edilirliğinin temel belirleyicilerindendir. Dolayısıyla, Instabloggerların daha fazla etkileşim getiren transformasyonel (dönüşümsel) mesaj stratejileri kullanmaları alan literatürüyle ve sektörel pratikle de uyumlu bir sonucu yansitmaktadir.

Son olarak; ana mesaj stratejileri ile Instabloggerların yaptıkları ürün yerleştirmeli paylaşımların yarattıkları etkileşim parametreleri arasındaki ilişki incelendiğinde, geçmiş çalışmalardan farklı bir sonuca ulaşılmıştır. Instabloggerların ürün yerleştirmeli paylaşımlarda kullandıkları bilgisel ve transformasyonel mesaj stratejileri aldıkları beğeni ve Instabloggerların yorum sayıları bağlamında anlamlı bir fark yaratmazken, takipçi yorumlarında anlamlı farklar ortaya koymaktadır. Bilgisel mesajlar transformasyonel (dönüşümsel) mesajlara göre anlamlı biçimde daha fazla takipçi yorumu almaktadır. Bu da Instabloggerların kullandıkları mesaj stratejileri bağlamında bir çelişkiyi içinde barındırmaktadır. Instabloggerların performans kriterlerinden biri olan etkileşimin belirleyicilerinden olan takipçi yorumları bilgisel mesaj stratejilerinde daha fazla olurken Instabloggerlar ürün yerleştirmeli paylaşımlarının sadece küçük bir kısmında (yaklaşık \%14) bilgisel mesaj stratejilerine yer vermektedir. Benzer şekilde, bilgisel mesaj stratejisi kullanılan paylaşımlardaki interaktif unsur sayısı (hashtag, tag, lokasyon bilgisi vb.) da transformasyonel mesajlara göre anlamlı biçimde daha fazladır. Bu durumu şu şekilde okumak mümkündür: Instabloggerlar ürün yerleștirme esnasında bilgi verirken takipçilerini ürün yerleştirmesi yapılan markanın sayfasına yönlendiriyor ya da satışa dönük olarak daha fazla etkileşim yaratmaya çalışıyor olabilir.

\subsection{Uygulamaya Yönelik Öneriler}

Çalışmanın bulguları, Instablogger'ın kullandığı mesaj stratejisinin tüketicilerle etkileşimi bağlamında anlamlı fark yarattığını göstermektedir. Bu çerçeveden değerlendirildiğinde, markalar Instablogger seçim kriterlerini belirlerken Instagram üzerinde ne gibi mesaj stratejisi kullandıklarını da bir parametre olarak değerlendirmelidir. Çünkü bilgisel ve dönüşümsel mesaj stratejileri söz konusu olduğunda takipçi yorumu alma anlamında farklılıklar söz konusudur. Takipçi yorumu, beğeni sayısı, Instablogger yorumu gibi etkileşim özellikleri günümüzde markaların Instablogger seçimlerinin önemli parametrelerindendir (Öztürk ve Şener 2018). Yapılan yatırımların geri dönüşü için mesaj stratejisinin yeni bir seçim kriteri olarak değerlendirilmesi önemlidir.

\subsection{Kısıtlılıklar}

Hâlihazırdaki çalışma alana katkı niteliğinde önemli iç görüler sunmakla beraber belirli kısıtlılıkları da içinde barındırmaktadır. $\mathrm{Bu}$ anlamda gelecekteki benzer 
çalışmalarda daha fazla Instagram hesabı kategorisinin dâhil edilerek farklı kategorilerdeki mesaj stratejilerinin incelenmesi, sadece tek bir sosyal medya platformunun değil diğer mecralarda da (Youtube, Twitter gibi) bu çalışmanın genişletilmesi, araștırmanın bulgularının genellenebilirliği açısından faydalı olacaktır.

\section{Kaynakça}

Aaker, D. A., Norris, D. (1982). Characteristics of TV commericals perceived as informative. Journal of Advertising Research, 22(2), 61-70.

Aaker, D. A., Stayman, D. M. (1992). Implementing the concept of transformational advertising. Psychology \& Marketing, 9(3), 237-253.

Balasubramanian, S. K. (1994). Beyond advertising and publicity: Hybrid messages and public policy issues. Journal of Advertising, 23(4), 29-46.

Böke, K. (2011). Örnekleme. K. Böke (Ed.). Sosyal Bilimlerde Araştırma Yöntemleri (3. bs.). İstanbul: Alfa.

Brown, D. ve Hayes, N. (2008). Influencer Marketing: Who Really Influences Your Customers? New York: Routledge.

Bones, B. (2017). Macro vs micro influencers-Which is best for your business? Erişim: 12 Ekim 2018, Fundera: https://www.fundera.com/blog/macro-vsmicro-influencers

Content Marketing Institute. (2016). Influencer marketing: The latest strategies, templates, anmd tools. Erişim: 14 Ekim 2018, https:// contentmarketinginstitute.com/wp-content/uploads/2016/10/Influencer_ eBook2016_FINAL.pdf

Flynn, L. R., Goldsmith, R. E., Eastman, J. K. (1996). The King and Summers opinion leadership scale. Journal of Business Research, 31(1), 55-64.

Freberg, K., Graham, K., McGaughey, K., Freberg, L. A. (2011). Who are the social media influencers? A study of public perceptions of personality. Public Relations Review, 37(1), 90-92.

Golan, G. J., Zaidner, L. (2008). Creative strategies in viral advertising: An application of Taylor's six-segment message strategy wheel.Journal of Computer-Mediated Communication. 13(4), 959-972.

Handriana, T., Wisandiko, W. R. (2017). Consumer attitudes toward advertisement and brand, based on the number of endorsers and product involvement: An experimental study. Gadjah Mada International Journal of Business, 19(3), 289-306.

Hang, H., Auty, S. (2011). Children playing branded video games: The impact of interactivity on product placement effectiveness. Journal of Consumer Psychology, 21(1), 65-72.

Hatton, G. (2018). Micro influencers vs macro influencers. Erişim: 12 Ekim 2018, SocialMediaToday: https://www.socialmediatoday.com/news/microinfluencers-vs-macro-influencers/516896/

Healey, J. F. (2015). Statistics: A Tool for Social Research (10. Bs.). Stamford, CT: Cengage Learning. 
Huffpost. (2016). What Is Influencer Marketing? Erişim: 16 Ekim 2018, https://www.huffingtonpost.com/global-yodel/what-is-influcnermarketing_b_10778128.html/

iAB Türkiye. (Temmuz 2016) Reklam Engelleme Raporu. Erişim: 19 Ekim 2018, https://www.iabturkiye.org/UploadFiles/Reports/ADBLOCKING_ EI_12_07_201605072017172342.pdf

iAB Türkiye. (2018). Influencer Pazarlaması Raporu. Erişim: 19 Ekim 2018, https:// www.iabturkiye.org/UploadFiles/Reports/inluencer762018162344.pdf

Katz, E., Lazarsfeld, P. F. (1995). Personal influence. New York, London: Routledge.

Krippendorff, K. (2004). Reliability in contentanalysis: Some common misconceptions and recommendations. Human Communication Research, 30(3), 411-433.

Kolcuoğlu, R. A. (2018). Instagramda Nüfuz Pazarlaması (Influencer Marketing) ve Doğal Reklamlar Üzerine Betimleyici Bir Araştırma. Yüksek Lisans Tezi, Akdeniz Üniversitesi, Antalya.

Kurutz, S. (2011). Fashion bloggers, posted and represented. Erişim: 10 Ekim 2018, The New York Times: https://www.nytimes.com/2011/09/29/fashion/ fashion-bloggers-get-agents.html

Laskey, H. A., Day, E., Crask, M. R. (1989). Typology of main message strategies for television commercials. Journal of Advertising, 18(1), 36-41.

Lazarsfeld, P. F., Berelson, B., Gaudet, H. (1944). The people's choice. New York: Duell, Sloan, and Pearce.

Linqua. (2017). The State of Influencer Marketing 2017. Erişim: 13 Ekim 2018, http:// www.linqia.com/wp-content/uploads/2016/11/The-State-of-InfluencerMarketing-2017_Final-Report.pdf

Linqua. (2018). The State of Influencer Marketing 2018. Erişim: 13 Ekim 2018, http://www.linqia.com/wp-content/uploads/2017/12/Linqia-The-State-ofInfluencer-Marketing-2018.pdf

Liu, S., Chou, C., Liao, H. (2015). An exploratory study of product placement in social media. Internet Research. 25(2), 300-316.

Lynn, T., Jaramillo, A., Muzellec, L. (2014). Extending the product placement research agenda: The impact of hypervideo on interactivity and timing of product placement decisions. The Marketing Review, 14(4), 339-360.

Lyons, B., Henderson, K. (2005). Opinion leadership in a computer-mediated environment. Journal of Consumer Behaviour, 4(5), 319-329.

Martensen, A., Brockenhuus-Schack, S., Zahid, A. L. (2018). How citizen influencers persuade their followers. Journal of Fashion Marketing and Management, $22(3), 335-353$.

McCracken, G. (1989). Who is the celebrity endorser? Cultural foundations of the endorsement process. Journal of Consumer Research, 16(3), 310-321.

Mediakix (2017). Erişim: 15 Ekim 2018, http://mediakix.com/2017/08/what-is-amacro-influencer-definition/\#gs.402vGSo 
Nielsen (Eylül 2015). Global Trust in Advertising: Winning Strategies for an Evolving Media Landscape. Erişim: 18 Ekim 2018, https://www.nielsen.com/content/ dam/ nielsenglobal/apac/docs/reports/2015/nielsen-global-trust-inadvertising-report-september-2015.pdf

Nisbet, M. C., Kotcher, J. E. (2009). A two-step flow of influence? Opinion leader campaigns on climate change. Science Communication, 30(3), 328-354.

O’Reilly, L. (31 Ocak 2017). Ad blocker usage is up 30\% - and a popular method publishers use to thwart it isn't working. Erișim: 20 Ekim 2018, Business Insider Ağ Sitesi: https://www.businessinsider.com/pagefair-2017-adblocking-report-2017-1

Osatuyi, B. (2013). Information sharing on social media sites. Computers in Human Behavior, 29, 2622-2631.

Özdemir, A. (2010). Yönetim Biliminde İleri Araştırma Yöntemleri ve Uygulamalar (2. Bs.). İstanbul: Beta.

Öztürk, E., Şener, G., Süher, H. K. (2016). Sosyal medya çağında ürün yerleştirme: Instagram ve Instabloggerlar üzerine bir içerik analizi. Global Media Journal TR Edition. 6(12), 355-386.

Öztürk, E., Şener, G. (2018). Modada nüfuz pazarlaması: Mikro Instabloggerların ürün yerleștirme uygulamaları. Selçuk Üniversitesi İletişim Fakültesi Akademik Dergisi, 11(1), 382-412.

Pallant, J. (2010). SPSS Survival Manual. New York: McGraw Hill.

Puto, C., Wells, D. (1984). Informational and transformational advertising: The differential effects of time. T. C. Kinnear (Ed.). Advances in Consumer Research (Sayı XI, s. 638-643). Ann Arbor, MI: Association of Consumer Research.

Reklamcılar Derneği. (Mart 2018). Türkiye'de Tahmini Medya ve Reklam Yatırımları Reklamcılar Derneği Raporu. Erişim: 18 Ekim 2018, http://rd.org.tr/www/ rd/assets/doc/RD-medya-ve-reklam-yatirimlari-2017-Raporu.pdf

Russell, C. A., Belch, M. (2005). A managerial investigation into the product placement industry. Journal of Advertising Research, 45(1), 73-92.

Sheth, J. N. (2018). How social media will impact marketing media. G. Heggde \& G. Shainesh (Ed.). Social Media Marketing (s.3-18). Singapur: Palgrave Macmillan.

Şener, G., Öztürk, E., Suher, H. K. (2016). Instaplacement and its effect on the perceived source credibility of Instabloggers: A study on the university university students. Aydemir Okay (Ed.). Trust in Communication Management. New York: Peter Lang.

Tafesse, W., Wien, A. (2017). A framework for categorizing social media posts. Cogent Business and Management, 4, 1-22.

Tafesse, W., Wien, A. (2018). Using message strategy to drive consumer behavioral engagement on social media. Journal of Consumer Marketing, 35(3), 241-253.

Taylor, R. E. (1999). A six-segment message strategy wheel. Journal of Advertising Research, 39(6), 7-17. 
van Reijmersdal, E. A., Neijens, P. C., Smit, E. G. (2007). Effects of television brand placement on brand image. Psychology \& Marketing, 24(5), 403-420.

We Are Social (Ocak 2018). Digital in 2018 in Western Asia Part 1 - North West. Erişim: 20 Ekim 2018, https://www.slideshare.net/wearesocial/digital-in2018-in-western-asia-part-1-northwest-86865983

Wei, M. L., Fischer, E., Main, K. J. (2008). An examination of the effects of activating persuasion knowledge on consumer response to brands engaging in covert marketing. Journal of Public Policy \& Marketing, 27(1), 34-44.

Wissman, B. (2018). Micro-influencers: The marketing force of the future? Erişim: 20 Ekim 2018, Forbes: https://www.forbes.com/sites/ barrettwissman/2018/03/02/micro-influencers-the-marketing-force-ofthe-future/\#2462a30c6707

Yoo, K., Gretzel, U., Zach, F. (2011). Travel opinion leaders and seekers. Information and Communication Technologies in Tourism Conference Proceedings (525535). Vienna: Springer.

Yüksel, A.H.(2003). İletişim Kavram ve Tanımı.U. Demiray (Ed.) Meslek Yüksekokulları için Genel İletişim. Ankara: Pegem Yayınları.

Zaichkowsky, J. (1985). Measuring the involvement construct. Journal of Consumer Research, 12, 341-352. 